\title{
Research
}

\section{Exploring the Role of Private Wildlife Ranching as a Conservation Tool in South Africa: Stakeholder Perspectives}

\author{
$\underline{\text { Jenny A. Cousins }}^{1}$, Jon P. Sadler ${ }^{2}$, and James Evans ${ }^{1}$
}

\begin{abstract}
Rich in biological diversity, South Africa's natural habitats are internationally recognized as a conservation priority. Biodiversity loss continues, however, and limited scope to enlarge the stateprotected areas, combined with funding shortages for public parks, means that conservationists are increasingly turning to private landowners for solutions. The recent boom in privately owned wildlife ranches in South Africa has the potential to contribute to conservation in South Africa. This paper explores the benefits, limitations, and challenges of private wildlife ranching as a tool for conservation in South Africa through interviews with key stakeholders working within conservation and wildlife ranching, and through case studies of threatened species programs. Respondents suggested that wildlife ranches contribute to conservation positively by maintaining natural areas of habitat and by providing resources to support reintroduction programs for threatened species. However, they reported a number of limitations centered on three themes that generally arise due to the commercial nature of wildlife ranching: (1) tourist preferences drive the industry, (2) predators are persecuted to protect valuable game, and (3) inadequate resources are made available for professional conservation management and planning on ranches. In addition to challenges of combining economic gain with conservation objectives, ranchers face a number of challenges that arise because of the small, enclosed character of many ranches in South Africa, including the need to intensively manage wildlife populations. In order to enhance the role of wildlife ranching within conservation, clear guidance and support for ranchers is likely to be required to boost endorsement and minimize economic loss to ranchers.
\end{abstract}

Key Words: conservation; private wildlife ranches; qualitative research; South Africa; stakeholder views

\section{INTRODUCTION}

South Africa is internationally acknowledged as a country rich in biological diversity. Covering only $2 \%$ of the global land area, it contains approximately $10 \%$ of the global total of plant species, $6 \%$ of mammal species, $7 \%$ of bird species, $5 \%$ of reptile species, and 6\% of insect species (Scholes and Biggs 2004, Department of Environmental Affairs and Tourism (DEAT) 2005). South Africa is home to over 18000 species of vascular plants, $80 \%$ of which are endemic, and the country contains three of the world's 34 biodiversity hotspots (Myers 2003); areas classified as such because of their high plant endemism and extensive habitat loss.

Since South Africa's ratification of the Convention on Biological Diversity in 1995, there have been considerable achievements in conservation including the development of a national policy on biodiversity and the expansion of area under conservation protection (Wynberg 2002). Despite this policy and legal framework, biodiversity is still being lost in South Africa (DEAT 2005). Out of the 19 southern African countries, South Africa holds the second highest number of threatened species (those listed as either critically endangered, endangered, or vulnerable), including 45 plants, 42 mammals, 28 birds, 19 reptiles, 9 amphibian, 29 fishes, 10 mollusks, and 102 other invertebrates, totalling 284 species (IUCN 2002). At a regional scale (i.e, southern Africa), an estimated 41 endemic plants and 12 endemic vertebrates have become extinct over the last two centuries (Golding 2002, IUCN 2002). The primary causes of species and habitat loss are conversion to cultivated land, followed by urban sprawl, alien plant invasion, and plantation forestry (Scholes and Biggs 2004). 
Financing conservation has become a major issue as state budgets and support for park management are diminishing in many provinces (Scriven and Eloff 2003, Botha 2001, Krug 2001, Leader Williams et al. 2005). The traditional approach of purchasing land for conservation, utilized globally, is not popular or even viable in the post-apartheid reform climate of South Africa, where $30 \%$ of land is targeted for redistribution to historically disadvantaged South Africans by 2015 (Conservation International 2007). The total land area covered by statutory protected areas, standing at around 5\% (Goodman et al. 2002), is not only too small to protect biodiversity in the long term (Krug 2001) but does not adequately represent all habitat types. With little scope to enlarge the network of public protected areas (Botha 2001) and with more than $80 \%$ of the land in South Africa in private hands (Patterson and Khosa 2005), including much rare habitat (Botha 2001), there have been calls for conservation to look outside of protected areas and involve private landowners (Krug 2001, Botha 2001, Scriven and Eloff 2003).

The recent expansion of privately owned wildlife ranches in South Africa is thought to have great potential to contribute to conservation in South Africa, and it is this form of private land use that this paper is concerned with. There are an estimated 9000 wildlife ranches in South Africa covering approximately 20.5 million ha (approximately $16.8 \%$ of the total land in South Africa) (National Agricultural Marketing Council (NAMC) 2006) and another 15000 landowners who are involved in both domestic livestock and wildlife ranching (Patterson and Khosa 2005). Large-scale conversion of livestock ranches to wildlife ranches (as a result of legislative change and the provision of excess animals from protected areas to private owners) led to numerous species being reintroduced to former domestic livestock farms. In recent years, a combination of forces, such as the decreasing profitability of cattle farming, increased stock theft, and the re-emergence of South Africa into the world community, has resulted in a sector shift to wildlife ranching.

The benefits provided to conservation from wildlife ranching seem to be well accepted by many working within the industry (including the Professional Hunters Association of South Africa (PHASA) 2007, African Indaba 2007, South African Hunters and Game Conservation Association 2007, KwaZulu-Natal Hunting and Conservation Association
2007, Helicon Services 2007, Thaba Manzi Wildlife Services 2007). However, there is surprisingly little literature regarding the role that private wildlife ranching plays in conservation. The information available often focuses on economic or business issues surrounding wildlife ranches (Amalgamated Banks of South Africa (ABSA) Group Economic Research 2003, Cloete et al. 2007, van der Merwe and Saayman 2003, van der Merwe et al. 2004) or their nature and distribution (Reilly et al. 2003) (and not their contribution to conservation). The same few examples of conservation successes are highlighted repeatedly, the most widely cited being the case of the Southern white rhinoceros (Ceratotherium simum simum) (see Lindsey et al. 2007, Hamman et al. 2005, Scriven and Eloff 2003). The other species listed as being saved from possible extinction by private landowners (including wildlife ranchers) include bontebok (Damaliscus dorcas), black wildebeest (Connochaetes gnou), Cape mountain zebra (Equus zebra zebra) (Flack 2003), and the geometric tortoise (Psammobates geometricus) (Hamman et al. 2005). Langholz and Kerley (2006) note the rich diversity of vegetation types that are being protected by ecotourism-based private wildlife reserves in the Eastern Cape, whereas Lindberg et al. (2003) highlight their contribution to increasing landscape connectivity in the KwaZulu-Natal (KZN) region of the country (Fig. 1). Goodman et al. (2002) note that two endemic plant communities, which are not present in the formal network of protected areas in KZN, are being supported by wildlife ranching.

Two main forms of wildlife production systems are recognized: extensive and intensive. This paper largely deals with the extensive system, which can be defined as the managed extensive production of free-living animals on large fenced or unfenced private or communal land, usually for the purposes of live sales, trophy hunting, wildlife meat, or tourism (Bothma 2002), although it should be noted that most wildlife ranches in South Africa are fenced. Live animals are usually sold through game capture teams or auctions (Ebedes 1994). The private commercial wildlife ventures dealt with in this paper include farms, ranches, reserves, and conservancies-names that often appear to be interchangeable and used according to the owner's preference. This paper is largely concerned with in situ conservation, which for the purpose of this paper can be defined as "the conservation of ecosystems and natural habitats and the maintenance and recovery of viable populations of 
Fig. 1. Map showing distribution of provinces in South Africa (Source: Department of Environmental Affairs and Tourism) and locations referred to in this paper.

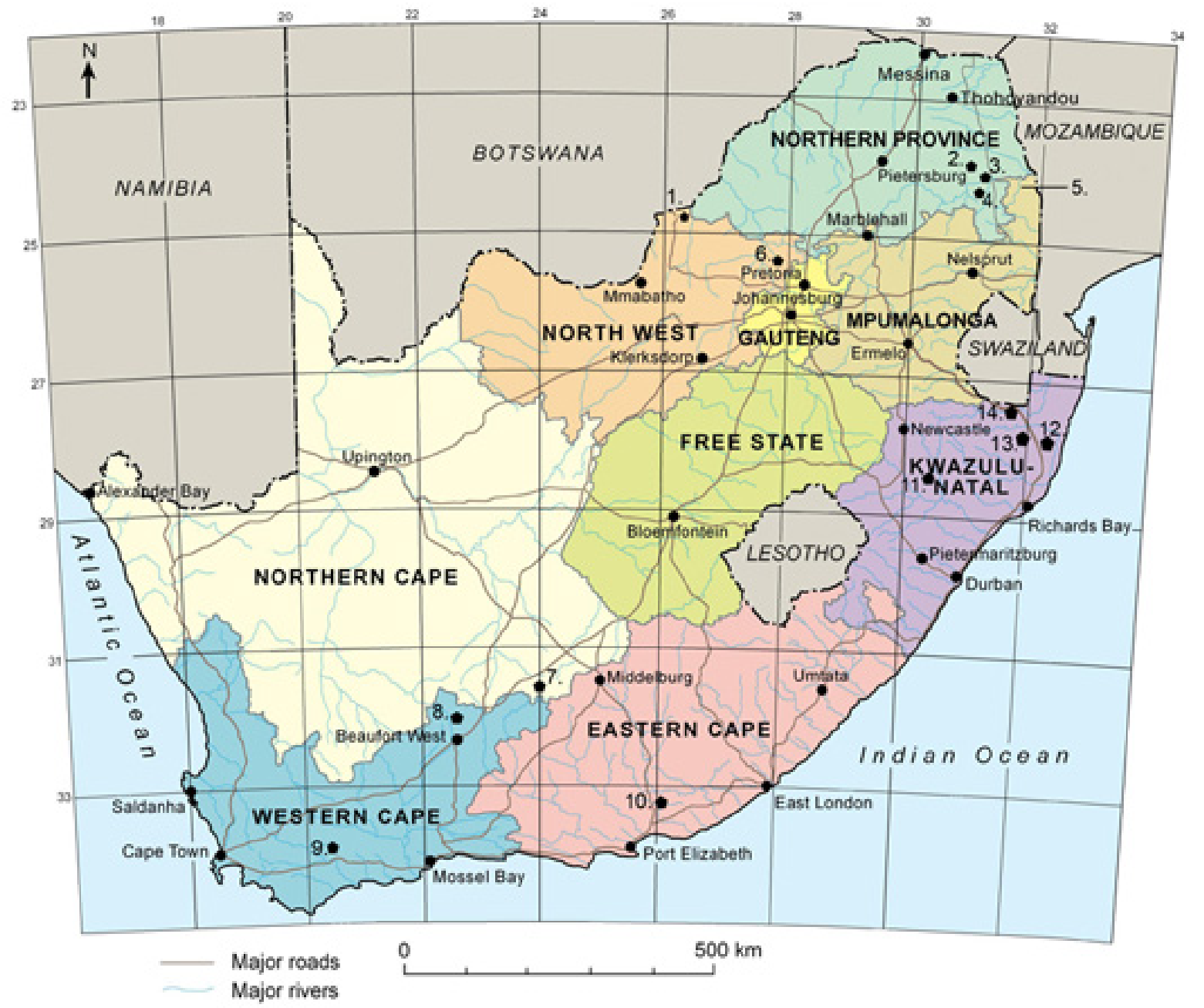

1. Madikwe East

2. Karongwe Game Reserve

3. Selati Game Reserve

4. Kapama Game Reserve

5. Kruger National Park

6. Mabula Private Game Reserve

7. Highover Wildlife Sanctuary
8. Thornhill

9. Sanbona Wildlife Reserve

10. Shamwari Game Reserve

11. Nambiti Conservancy

12. Munyawana Game Reserve

13. Zululand Rhino Reserve

14. Pongola Game Reserve 
species in their natural surroundings and, in the case of domesticated or cultivated species, in the surroundings where they have developed their distinctive properties" (The Convention on Biological Diversity 1993, article 2).

This paper explores the benefits, limitations, and challenges of private wildlife ranching as a tool for conservation in South Africa, through interviews with stakeholders working within conservation and wildlife ranching, and case studies of threatened species programs. These research topics are explored in turn in the main three sections of this paper.

\section{METHOD}

In recent literature, a number of conservationists have voiced their interest in incorporating the more contextual analyses drawn from the social sciences into conservation biology (see Meine et al. 2006, Robinson 2006). This paper approaches the topic from a social science perspective. We used a qualitative approach to the research, drawing upon the following sources of evidence: semi-structured interviews with stakeholders involved in (1) national and provincial government, (2) conservation non-governmental organizations (NGOs), and (3) the wildlife ranching industry. In a second stage to the research design, we drew upon case studies of threatened species programs. The views of those involved in wildlife ranching and conservation are critical to understanding the role of private wildlife ranching as a conservation tool. The use of semistructured interviews also allowed the views of different stakeholder groups to be put into play against each other, staging an indirect dialogue that produced more nuanced conversations. In addition, this study offers an insight into the workings of private wildlife ranches in South Africa and the challenges of conservation within a private economic setting. Research was carried out between October 2006 and August 2007, including a total of 4.5 months in South Africa. Of that period, 4.5 months included time spent with ecologists, wildlife experts, rangers, hunters, and management personnel on private hunting ranches, private wildlife viewing ranches, a number of national parks and 1 month with a game capture team.

Respondents were selected on the basis of their experience related to the research topic and were targeted within the groups previously stated.
Respondents were further selected using snowball sampling (Clifford and Valentine 2005). Stakeholders include representatives from within the national government (including the Biodiversity and Conservation Branch of the DEAT, from within the provincial departments dealing with nature conservation (including Nature Conservation), NGOs (including large South African conservation organizations and smaller organizations offering ecological monitoring services to ranches), and representatives of the wildlife ranching industry (including Wildlife Ranching South Africa, wildlife managers on private wildlife reserves, professional hunters, and game capture teams). Twenty-five informants supplied formal information for this paper through prearranged interviews. Of these, eight were from within the government, 14 from conservation NGOs, and three from within the wildlife ranching industry. In addition, site visits were undertaken to a number of private wildlife ranches where numerous discussions were engaged in and observations were made as the opportunity arose, including discussions with those working within the ranching industry (largely game capture, hunting, veterinary, and management) in which detailed notes were taken, amounting to 15 further interviews. It should be noted that a number of persons within the provincial government departments did not wish to participate. This was largely due to their feelings of not knowing enough about private ranching and conservation. Notwithstanding, the sample captures a representative reflection of opinions from those involved in conservation and wildlife ranching in South Africa today. Anonymity of the participants has been respected.

Semi-structured interviews were used to investigate stakeholder opinions. Interviewing "is one of the most common and powerful ways in which we try to understand our fellow humans" (Fontana and Frey 2005: 697-698) and enable the researcher to get large amounts of data quickly (Marshall and Rossman 1995). Semi-structured interviews ensured a consistent range of topics were covered, allowed a flexible approach to questioning, and gathered opinions and behaviors in the informants' own words (Dunn 2005, Longhurst 2003). The interviews centered on a number of broad predetermined themes (including contributions to conservation, detrimental effects on or limitations to conservation, challenges to conservation on private wildlife ranches) although questions were designed in view of the respondent's area of 
expertise. Semi-structured interviews were largely conducted face to face, but on a number of occasions by telephone and email. All interview data were transcribed and coded to identify key reoccurring themes relating to the research area (Strauss and Corbin 1990, Cope 2005).

The case-study approach is useful when investigating a phenomenon within its real-life context (Yin 1994), and provides depth and quality of data. Case studies of threatened species programs provided further depth of information regarding species conservation on private wildlife ranches. Case-study species were selected based on their threatened status within South Africa and having a current conservation program, and include the blue swallow (Hirundo atrocaerulea), riverine rabbit (Bunolagus monticularis), southern ground hornbill (Bucorvus leadbeateri), and black rhinoceros (Diceros bicornis).

\section{WILDLIFE RANCHING AND CONSERVATION BENEFITS}

Most respondents report that the greatest role wildlife ranches play in contributing to conservation is in maintaining natural areas. With limited government funding available for conservation, many respondents feel that the role of private ranches is essential, for example, a representative of the government department in Gauteng stated:

Official nature conservation institutions don't have the necessary budgets to maintain all the natural landscapes and, therefore, many private landowners have contributed to keeping these landscapes untransformed. (Provincial Government official, Gauteng Nature Conservation, 2007.)

According to a conservation coordinator for a large conservation NGO, wildlife ranches "are maintaining habitat that another land use such as agriculture or development would not be doing" (NGO/Conservation Coordinator 2007). Maintaining natural areas is obviously advantageous and protects habitat from radical transformation. For example, in Limpopo Province (formally Northern Province), Selati Game Reserve (30 500 ha) protects a large number of endemic cycad plants (Cycas spp.), and in the North West Province "several of the private wildlife ranches are located in areas where there are ecologically significant habitat types" (Provincial
Government, North West Province, Biodiversity Scientific Support 2007). According to a representative from the DEAT, many more vegetation types are covered by private wildlife ranches than by formally protected areas.

By maintaining habitat, ranches are also providing additional space for a variety of species, both introduced by the rancher and non-introduced (Bojö 1996). This additional space, according to one interviewee, supports formal conservation as ranchers become "custodians of components of meta-populations" (Representative of the Game Rangers Association and African liaison and representative to IUCN 2007). Mixed ranches of livestock and game can also provide benefits to wildlife. For example, in the central and southwestern Karoo region, Machange et al. (2005) found that the density of Martial Eagle (Polemaetus bellicosus) pairs was significantly higher in game or mixed farming areas than in areas with domestic stock only.

Some species may already be present before conversion to a wildlife ranch occurs, whereas others may colonize the property at a later date. For example, on Nambiti Conservancy (a 10 000-ha ecotourism ranch) in KwaZulu-Natal, four blue cranes (Anthropoides paradisea) (the national bird of South Africa) have naturally colonized the property since its conversion to a wildlife ranch. This former cattle ranch now provides secure habitat for a vast variety of amphibians, reptiles, birds, and small mammals. The critically endangered blue swallow and riverine rabbit (Evans and Barnes 2000, Friedmann and Daly 2004) are also benefiting from private wildlife ranches in South Africa according to our case-study data. A representative involved in the riverine rabbit's conservation at Sanbona Wildlife Reserve (a large private ranch of $54000 \mathrm{ha}$ ) thinks that the ranch could become an important player in the rabbit's conservation as it already functions as a refuge for the species from agricultural activities, hunting, and poaching. A field survey in September 2006 sighted five riverine rabbits on the reserve and the reserve's management team plan to cooperate closely with Cape Nature and the Endangered Wildlife Trust's Riverine Rabbit Working Group to monitor and manage the rabbits. In addition to this, the riverine rabbit is a focus species for the reserve's marketing:

At this stage, we are focusing on making people aware of the status of this species. 
The reserve has also started to use the rabbit as a marketing tool to market the conservation efforts of the reserve-this is a challenging project because most of the time people look at the bigger species tourism wise, but at this stage it's working well. (NGO, Sanbona Wildlife Reserve, Wildlife Division, 2007.)

It appears that the work on Sanbona will not only help conserve the rabbit, but also create a greater interest in the species and raise awareness of its plight.

The blue swallow is present on two private ranches in KwaZulu-Natal. Highover Sanctuary (3000 ha in the Hella-Hella area) is an important site that has had five active nest sites in the past. According to a fieldworker for the KwaZulu-Natal (KZN) Biodiversity Program the outlook for Highover is uncertain, however, as it is under land claim and its future depends on the new owner's intentions. The Endangered Wildlife Trust's Blue Swallow Working group is currently working with the owners and the community (including possible future owners), and hopes to establish a mutually beneficial partnership:

The management of this site is very goodthe birds and nests are monitored throughout the breeding season and visitors are not allowed to disturb the nesting sites. In terms of ecotourism, it is in the interests of the reserve to conserve the blue swallow amongst other things as a good selling point. (NGO, KZN Biodiversity Program, 2007.)

The other property in KwaZulu-Natal plays a less active role in the bird's conservation, although the presence of the ranch is seen as beneficial in keeping the land use stable:

The majority of visitors to this property are trophy hunters and are not always keen birders. The fact that this is a blue swallow site is more by chance/coincidence. This said, it contributes in the sense that this farming method is unlikely to change the land use. (NGO, KZN Biodiversity Program, 2007.)

Reintroduction programs have been used primarily to increase species populations on wildlife ranches where they were have become locally extinct or declined significantly (Hall-Martin and Castley 2003, Scriven and Eloff 2003, Steenkamp et al. 2005). Interviewees suggest that the reintroduction of lions (Panthera leo) has been highly successful, with success stories in KwaZulu-Natal and Limpopo. One interviewee, an ecologist who monitors a reintroduced pride of lions, suggests that predator reintroductions are important because they "reinstate processes such as predation and competition" (NGO, Ecological Services, Manager 2006). Hayward et al. (2007) note that in the Eastern Cape, 11 conservation areas have reintroduced large predators since 1996, and there is an extant population of 56 lions. According to a representative of a wildlife monitoring organization on private wildlife ranches, cheetah (Acinonyx jubatus) and leopard (Panthera pardus) are heavily persecuted outside of protected areas and "problem" individuals are often relocated through organizations such as De Wildt Cheetah and Wildlife Trust to the safety of private wildlife viewing ranches. Increasingly, wildlife ranchers are working with conservation groups and are providing considerable resources in order to re-establish rare species onto their properties, as revealed in our case-study data. For example, the southern ground hornbill, currently classed as vulnerable (Kemp 2000), has been reintroduced at the 10 000-ha Mabula Private Game Reserve in Limpopo as part of a project to return these large, savannah-dwelling, carnivorous birds to areas where they were previously present. According to a representative of the Mabula Ground Hornbill Conservation Project, second-hatched chicks (which otherwise die of starvation) are harvested from state land, including Kruger National Park (2 million ha), and are then hand reared at Mabula for eventual release outside of officially protected areas. The interviewee describes the eagerness and commitment of the ranch owners:

We are invited all the time now to do site inspections on private game farms, to see if they are suitable, which entails considerable commitment on the part of the landowners, with a shepherd full time following, protecting, and feeding them for at least 2 to 3 years. (NGO, Mabula Ground Hornbill Conservation Project, 2007.)

Birds have been released onto a number of private ranches specializing in wildlife viewing as part of this program, including Madikwe East (15 000 ha), 
Shamwari (20 000 ha), and most recently, a new 40 000-ha conservancy next to Mabula. The partnership appears to be of benefit to both parties:

We were approached by them a year ago. They want the birds I suppose as they are very dramatic in the veld and are in need of conservation. Huge help from these people, they are very keen to get the birds breeding. They are doing everything we ask for, money for transmitters and telemetry, fuel, and the use of their workers. (NGO, Mabula Ground Hornbill Conservation Project, 2007.)

Like the hornbill, the recovery of the black rhino on private land has been supported by state-protected areas and it is only in the last 10-15 years that the private sector has become involved in black rhino conservation in South Africa (Leader-Williams et al. 2005). According to a representative of the World Wildlife Fund (WWF) Ezemvelo KZN Wildlife Black Rhino Range Expansion Project, private wildlife ranches are extremely important for black rhino conservation:

State-owned conservation areas are probably close to the ecological carrying capacity, and without partnerships with the private or community landowners, no other land could be set aside for black rhino conservation and other species' conservation. Talking of KwaZulu-Natal Province only, $15 \%$ of black rhino are now on private land through our project-that's 397 on state land and 62 on private land. (NGO, WWF Ezemvelo KZN Wildlife Black Rhino Range Expansion Project, 2007.)

This project aims to increase numbers of the critically endangered black rhino by increasing the land available for their conservation, thus reducing pressure on existing reserves and providing new territory in which they can breed quickly. It does this by facilitating partnerships between neighboring landowners in order to create large areas of land with good black rhino habitat. Similarly, this partnership also requires much dedication from the landowners:

In order to qualify to receive black rhino, game ranches need to meet certain criteria in terms of security, size, monitoring of the rhinos, and benefits to neighboring communities. The private landowners need to be prepared to contribute meaningfully in cash or kind to the protection of the black rhino. The deal is that the founders remain the property of the state and the offspring are shared equally between the landowners and the state. (NGO, WWF Ezemvelo KZN Black Rhino Range Expansion Project, 2007.)

The project has introduced three new populations onto private land. All three ranches (Munyawana Game Reserve (20000 ha), Zululand Rhino Reserve (20 000 ha), and Pongola Game Reserve (13 000 ha)) are commercial wildlife viewing ventures that were created by landowners combining their land in order to receive black rhino. According to the project leader, a future challenge for the project will be the further distribution of rhino from private ranch to private ranch, and their genetic management.

In addition to creating space for wildlife, respondents from the hunting and wildlife capture industry highlight the role of ranches in breeding rare species. For example, a professional hunter in the Free State stated:

There wouldn't be any animals around if we didn't breed them for hunting. So without us breeding animals up, many would have gone extinct already. (Wildlife Ranching Industry, Professional Hunter, 2007.)

This view is widely held among those involved in the hunting and game capture industry, but some dispute the role of breeding programs. For example, one interviewee from a well-known conservation organization stated:

How many recommendations are for breeding? And how does this address the threats? Is this not for ecotourism/hunting/ sales? It is not to say this is a problem, but in order to be cited as a conservation project, it needs to be addressing the threats and following recommendations, and in very few cases, is breeding the problem and the solution. Black rhino need habitat not farms. (NGO, Conservationist, 2007.)

This interviewee highlights a distinction between simply ranching wildlife and ranching wildlife following conservation recommendations. 


\section{CONSERVATION LIMITATIONS}

Despite the benefits that wildlife ranching provides, there are a number of limiting factors that restrict this contribution. The limitations described by the informants generally arise due to the commercial nature of wildlife ranching, and center on these three themes: (1) hunter and wildlife viewing tourist preferences drive the industry, (2) predators are persecuted to protect valuable game, and (3) inadequate resources are made available for professional conservation management and planning on ranches. The following sections expand on these shortcomings, consecutively.

\section{Demand-Driven Wildlife Ranching}

A number of provincial government department interviewees voiced their concerns regarding the unstable nature of private wildlife ranching. Ranching is largely profit driven, and if demand for wildlife lessens, the concern is that ranches may be converted to a more economically viable land use, for example:

\begin{abstract}
Private ownership of private nature reserves can be very unstable and often doesn't have a guarantee for ecosystem maintenance or protection over the long term. Reasons being that competition for more profitable land uses can easily change the current land use to more profitable land uses, like subdivision for smaller agricultural units, mining ofnon-renewable resources, township developments, or agroindustries. (Provincial Government, Gauteng Nature Conservation, Ecological Services, 2007.)
\end{abstract}

In addition to the changing demands of land use, it was suggested by a number of interviewees (working for conservation NGOs) that within wildlife ranching, demand for specific wildlife species has led to an uneven representation of biomes and species under wildlife ranch management. According to a representative of the Endangered Wildlife Trust Blue Swallow Working Group (2007), wildlife ranches in South Africa largely only conserve savannah habitats:

The distribution of game farms in South Africa has largely been determined by the distribution of the so-called big five, the distribution of which is largely in the savannah biome. For this reason, a disproportionate number of game farms are in the eastern and northern parts of South Africa within the savannah biome, and not within other biomes such as grassland. This is also why the savannah biome is considered to be one of the most protected of all the biomes in South Africa, and the grassland biome is considered to be the least protected. (NGO, Blue Swallow Working Group, 2007.)

This suggested bias toward savannah biomes seems to indicate that some species benefit more from wildlife ranches than others. As previously stated, species such as the riverine rabbit and blue swallow do benefit from private wildlife ranches, however, according to a number of interviewees, this contribution is very limited. Drawing from our casestudy data, it becomes apparent that none of the key blue swallow locations (a grassland species) are on private wildlife ranches, and perhaps ironically, most nest sites are on private commercial agricultural fields:

Game farms do not play a significant role in the conservation of the blue swallow purely because there are not many game farms in the distribution range of these birds. (NGO, KZN Biodiversity Program, 2007.)

In fact, of the 55 known active blue swallow nest sites in South Africa, 43 occur in KZN, and only two of these are on private wildlife ranches. The other blue swallow nest sites are in the provinces of Limpopo and Mpumalanga-neither of which have nests within private wildlife ranches. In Limpopo, most of the wildlife ranches are in bushveld areas "which are unsuitable for blue swallows" (NGO, Blue Swallow Working Group, Limpopo Representative, 2007). Similarly, the riverine rabbit was said to occur mainly outside of private wildlife ranches in South Africa:

The rabbit occurs mostly in the central Karoo, which is a hotspot in terms of commercial sheep farming in South Africa. Most of the game farms fall outside the riverine rabbit habitat distribution in the Western Cape Province and the majority of them have no riverine rabbit occurrence, except two-Sanbona and Thornhill. 
(NGO, Riverine Rabbit Working Group, Conservation Services, 2007.)

Further to this seemingly uneven representation of habitats and species, a number of respondents working within NGOs, and the provincial and national governments suggested that the stocking and breeding of various species on private wildlife ranches is generally demand driven, and often not undertaken for any clear conservation goals. One interviewee (who works within the Eastern Cape) does acknowledge that benefits can arise from ranching, but also notes how they are largely coincidental and depend on the general public's preferences:

While in some cases, a public demand to see (in the case of ecotourism) or shoot (in the case of hunting) a particular species might have positive spin-offs for conservation as it results in concerted effort, time, and resources being put into the habitat protection and breeding of that species, this is not always the case. The general public do not necessarily know what they should be seeing and what they should not be seeing, and the landowner may or may not have a conservation ethic. (NGO, Conservation Coordinator, 2007.)

Another interviewee similarly notes that wildlife ranch owners are "often profit driven vs. conservation driven - if it pays they will have it" (NGO, Game Rangers Association, African liaison and representative to IUCN, 2007). This can mean that species such as the endangered wild dog (Lycaon pictus), which according to one interviewee (who has first-hand experience of monitoring wild dogs on private ranches), are costly to maintain, are therefore less in demand by ranchers:

They are not quite as in demand as other predators......everyone has got images of wild dogs as dustbins-they devour everything. They are very expensive animals to maintain because they eat so much; a pack like these four we had, they would probably kill everyday. You really do need something like a massive impala population or a massive blesbok population to sustain wild dog packs. (NGO, Research and Monitoring Services, Operations Director, 2006.)
Typically, it is the number of game farms, tourists, and trophy hunters that is significant in determining the demand and price of specific game (van der Merwe et al. 2004) and certain species of wildlife go in and out of fashion, impacting on their salability and price. A manager of a game capture team (whose job it is to buy, sell, and translocate animals between ranches) describes the trends he has noticed:

It is getting more difficult to sell black wildebeest now, and roan is taking a big dip at the moment. And this red impala.....this rare species.....it was funny for everybody 3 years ago when they just discovered it, but now....... what do people do with it? (Wildlife Ranching Industry, Game Capture Company, Director, 2007.)

Novel species, which are often initially in high demand, can become less popular with time and are difficult to sell. It would be reasonable to suggest, therefore, that the breeding programs of these uncommon species may not always be managed in the long-term interests of the species involved. One interviewee working as a provincial government ecologist describes their concerns over the genetic fitness of species bred in demand-driven breeding programs:

Breeding of a wild rare species often has a market force behind it, and this interest rate simply wants more numbers, so multiplying becomes the only norm, and not the genetic fitness of the species. The overall nature of this practice is having a domestication effect on the species, changing it into a commodity like a farm animal, and thereby ignoring its behavioral ecology responsible for its genetic fitness. (Provincial Government, Gauteng Nature Conservation, Ecological Services, 2007.)

Another interviewee notes how public preferences can drive the stocking of exotic and extralimital species, which can be damaging not only for the species being introduced, but also for the species already present:

The stocking of exotic and extralimital species may increase the species diversity on a ranch, but it does nothing to benefit conservation and can have negative impacts on the natural habitat, indigenous species, and the introduced species 
themselves. (In the Eastern Cape) giraffe are often seen on private game reserves, brought in because the game reserves claim their visitors demand to see them-it's unclear whether giraffe were ever in these areas, but a number of scientists believe that they were not. There are cases of giraffe dying because they are not adapted to the habitat, and are simply being replaced with more and more. Nyala and waterbuck are being introduced onto game reserves where they never occurred naturally and they are out-competing the natural species. (NGO, Conservation Coordinator, 2007.)

Similarly, Smith and Wilson (2002) note that the foreign ecotourist and the hunting market have been strong driving forces behind the introduction of extralimital species. A number of authors (see Green and Rothstein 1998, Castley et al. 2001, Hamman et al. 2005) have described the negative long-term consequences of introducing alien or extralimital species to a ranch, potentially causing (1) hybridization, inbreeding, and competition with local taxa, (2) the introduction of foreign pathogens and parasites, and (3) habitat destruction. Numerous introductions of species outside of their natural range were witnessed by one author while in South Africa (JC), who also witnessed black and blue wildebeest being reintroduced onto the same farm in Gauteng, resulting in a potential hybridization risk.

Many respondents spoke of the appreciation of only a small proportion of species diversity by tourists, largely the "big five" (buffalo (Syncerus caffer), elephant (Loxodonta africana), leopard, lion, and rhinoceros), leading to the stocking of high numbers of these species. This is in accord with reports in the literature (see Langholz and Kerley 2006). Species such as lion and elephant are extremely popular species, especially within wildlife-viewing operations, and a number of interviewees whose job it is to monitor wildlife on ranches spoke of overpopulation problems arising with both species. In order to maximize tourism revenue on a small ranch, it was suggested that ranchers sometimes stock a small quantity of a wide variety of species. However, there is little value in having single animals, such as a black rhino, or populations with only two or three animals (Hall-Martin and Castley 2003).

\section{Predator Persecution}

Ranches that specialize in antelope breeding and hunting, especially those of high commercial value, often exclude predators. One interviewee (who has worked within the ranching industry for the past 15 years) explains how the trapping of caracal (Caracal caracal) and the hunting of black-backed jackal (Canis mesomelas) on ranches such as this is fairly common:

Farmers don't like them as they kill and eat young antelope. They may be moved to another farm or sometimes they are shot. But jackals won't go into traps, they are too cunning, so you have to hunt them with dogs or go shooting. Whereas cats, all you have to do is put a mirror or something or tie cans together (in the trap).......you don't even need meat because they are so curious. (Wildlife Ranching Industry, Game Capture Company, Director, 2007.)

One of us (JC) witnessed traps laid out for the purpose of catching small predators, such as caracal, on an antelope hunting farm in the Eastern Cape Province. One interviewee noted that "free-roaming predators are often killed without a permit" (Provincial Government, North West Province, Scientist, 2007) agreeing with recent literature, which comments on the eradication of transitory predators from wildlife ranches (Bothma 2004, Lindsey et al. 2005, 2006).

\section{Inadequate Management for Conservation}

A number of respondents from conservation NGOs and provincial government report that ranches are largely managed for profit rather than the biodiversity of the ranch, for example:

Most game farms are managed to accommodate certain species, and not for their ecosystem health and biodiversity. Veld management is often to accommodate hunting, walking, and driving, and not the biodiversity of the farm. (NGO, Conservation Ecologist, 2007.)

Similarly:

They do not appoint appropriately trained staff to manage their biodiversity; all the 
attention and resources go for the appointment of public relations staff, marketing staff, and hospitality management staff. (Provincial Government, Gauteng Nature Conservation, Ecological Services, 2007.)

\section{Likewise:}

All landowners by law must clear alien invasive species brought in historically, however, this is time consuming and costly, and their removal is not always managed effectively. (NGO, Conservation Coordinator, 2007.)

This bias toward business objectives over conservation, and an inadequate knowledge of conservation ecology are seen by some respondents as the most fundamental limitation. A representative from Cape Nature Conservation voiced their concerns regarding the lack of ecological management plans on most ranches. Ranches according to this interviewee are "usually managed by trial and error" (Provincial Government, Cape Nature Conservation, Scientific Investigations and Authorisations, 2007). Bigalke (2000) notes that there is evidence of poor performance on at least some private properties in the Mpumalanga Province, including overstocking, overgrazing, and a lack of understanding of the necessary ecological principles to ensure sound management (Zunckel and de Wet 1994). Many respondents would like to see a greater level of ecological monitoring on ranches, leading to more informed management decisions. An interviewee from a wildlife monitoring organization on private wildlife ranches noted that many introductions involving large game receive insufficient preparation and post-release monitoring, sometimes leading to unnecessary deaths and/or the escape of rare and endangered species such as cheetah. Furthermore, one interviewee noted that game-proof fences, erected to keep costly game within the ranch, "cause havoc and kill many smaller species" (NGO, Conservationist, 2007). Boone and Hobbs (2004) describe the damage that fences can cause to wildlife, including prevention of access to key resources, disruption to migratory routes, injury, and death.

\section{CHALLENGES FACED}

The practicality of ranching wildlife for conservation is challenging. The small size of many ranches in South Africa exacerbates these challenges because they need more intensive management. Small enclosed ranches prevent natural dispersion, emigration, and dispersal of juveniles, and the immigration of new individuals that create diversity in local gene pools (Hunter et al. 2007, Lehmann et al. 2008). Furthermore, Boone and Hobbs (2004) show how fencing parcels of land may reduce the carrying capacity of a landscape, thus reducing the number of game that can be supported. Therefore, it becomes the rancher's role to regulate the number of specific species on the ranch, manage their gene pool, and also regulate the predator:prey ratio for those ranches with predators.

One interviewee, who works for a non-profit conservation organization specializing in research and wildlife management on small enclosed ecosystems, spoke about how problems of overpopulation (of species such as lion and elephant) have been a sudden realization for some ranchers who are now faced with deciding how to regulate them. A lack of forethought and the unknown consequences of fences has led, according to a number of respondents, to species such as lion and elephant becoming overabundant on many enclosed ranches since reintroduction, impacting on habitat and other species present. One respondent described how fences have caused changes in elephant behavior:

Small reserves especially are breaking a lot of rules.........elephant calving intervals for instance are between 4 and 9 years between each calf, yet on Karongwe, we were popping them out every 2 years and 2 months. Your population sizes are doubling in 2 years because every cow in the population is having another calf every 2 years. A lot of people didn't realize the extent of the impact of fences. Fences have affected their behavior so much-their breeding rates and their feeding patternsand only now, in the last 10 years, people are starting to realize. The decisions that were made were not long term........so it's all gone horribly pear shaped for some people. (NGO, Research and Monitoring Services, Operations Director, 2006.) 
Elephants were repeatedly reported by the interviewees as an extremely big problem in South Africa, causing huge damage to the veld. Respondents also reported detrimental consequences of having high numbers (or even just the presence) of lions on ranches. For example, in 2006-2007, one adult cheetah, five cheetah cubs of various ages, and one adult spotted hyena (Crocuta crocuta) (all introduced) have died on a ranch in KwaZulu-Natal, and according to the director of a wildlife monitoring organization on the ranch, the deaths are directly and indirectly (in the case of the female adult cheetah) attributed to a high lion load on a small area. There are currently four adult lions on this ranch, with the likelihood of cubs being born in the coming year. The damage that lions can cause to other predators is well documented. Hayward et al. (2007) found that reintroductions of cheetah have been less successful where lions are the dominant predator, although there is a paucity of information on the impact of large predators on smaller predators such as serval (Leptailurus serval) and caracal on private ranches.

The management of these large mammals is a challenge and a number of management solutions are currently in use to control elephant and lion numbers. However, the "correct" way in which to control numbers is a topic of much discussion and disagreement in South Africa. Within National Parks and very large ranches, culling has been employed as one option to reduce elephant numbers. Elephant calves may sometimes be sold to elephantback safari companies. On smaller reserves, it is common for both elephants and lions to be injected with contraceptives to restrict breeding. On Nambiti Conservancy, for example, both female lions were given a contraceptive injection (effective for 1 year) before they were released onto the ranch. Each year, the decision must be made whether to administer contraceptives or allow one or both lionesses to reproduce. Male lions are sometimes vasectomized to prevent overpopulation and also inbreeding. An alternative option that is sometimes employed in order to prevent inbreeding is "swapping a small number of lions between two ranches with different bloodlines for mutual benefit" (NGO, Manager, 2006). According to a number of interviewees working on private hunting and ecotourism ranches, it is standard practice to remove the cubs of lions and cheetahs on enclosed reserves to prevent inbreeding (unless it's an exceptionally large reserve). Cubs are sold usually by the age of 1.5 years to other ranches. In KwaZulu-Natal and Limpopo provinces, it can, however, be difficult, sometimes impossible to relocate them:

There are still prices for cats. I mean you want to make sure that it goes to a good home, I mean Paul [sic] was always very adamant about not selling to hunting farms. In the end, you kind of get to a point where you have no other option, and he eventually had to shoot two of the male lions. They got to the age of three and a half, and they still couldn't find a home for them and they were trying to mate with their aunt. In the whole scheme of things, it was better for the reserve (name removed for anonymity) to have them hunted because it provides the reserve with more money to conserve the rest. (NGO, Research and Monitoring Services, Operations Director, 2006.)

A similar situation was reported for elephants:

(In KwaZulu-Natal) it's getting to saturation point-there is no price for elephants, you can't give them away. (NGO, Research and Monitoring Services, Researcher, 2006.)

Despite these reported difficulties, predators may still be allowed to breed. According to one interviewee, allowing predators to breed is good for tourism and also good for the well being of the animals.

Careful management is required for those ranches with predators to prevent the depletion of prey populations. On Nambiti Conservancy, for example, the monitoring of prey populations has shown that the predator:prey balance has yet to be met, and more blesbok (Damaliscus dorcas phillpsi) and impala (Aepyceros melampus) will need to be brought in as this popular prey species has been depleted. Bothma (2004) notes how lion reintroductions usually lead to rapid prey population declines, irrespective of initial population size, and Druce et al. (2004) state the need for both predator and prey populations within these small areas to be constantly monitored and managed. Preferred prey populations need to be kept large enough to sustain predator populations, but also to prevent inbreeding among the prey species. According to a number of interviewees, depleted populations can lead to 
inbreeding, and further reintroductions need careful management to ensure that enough rams are reintroduced.

There is widespread use of large numbers of "buffer animals" (species such as impala and warthog (Phacochoerus africanus), which are relatively cheap and common) with the aim of reducing predation on more expensive and rare species. There is growing evidence, however, that the use of buffer animals is ineffective (e.g, Lehmann et al. 2008). In some cases, predators may be removed with the aim of splitting up specific coalitions in order to reduce prey mortality, particularly in cases where charismatic or expensive species are being targeted, for example:

\section{At Kapama (the reserve), it was decided that they would remove one (lion) from the coalition because they were pulling down up to four giraffe a week, which is wasteful for lions, they cannot even eat one giraffe in a week. (NGO, Research and Monitoring Services, Operations Director, 2006.)}

A number of respondents suggested that the removal of fences and the aggregation of ranches would lessen the impact of ranching on wildlife and reduce the need for intensive management. Indeed, an increasing number of conservancies (a group of adjoining private commercial farms operating under a cooperative management agreement (ABSA Group Economic Research 2003)) already exist in some regions of South Africa such as Limpopo. The removal of fences, however, poses challenges in itself when economics are involved, as this interviewee notes:

\section{More farms should drop fences and not be so concerned with private ownership of animals as they currently are, but when animals have financial value this poses a challenge. (NGO, Conservationist, 2007.)}

Further challenges of keeping large animals, such as lions and elephants, on small ranches include problems associated with over-habituation, which can occur when animals are viewed daily, particularly for example if there is only one pride of lions on the ranch. The director of an ecological monitoring organization described the need for habituated animals on tourism ranches, but also noted the problems that this can cause. Animals that become over-habituated and a danger to humans may be destroyed. Another balance that needs to be found according to the manager of an ecological services company in Limpopo is the use of scientific language in reports produced for the ranching industry. Those with scientific credentials want to incorporate more science into ranching, and our respondents felt that the science required translation into a more user-friendly form. Those interviewees working in the ranching industry without a science background generally felt that they had more practical experience than scientists, and that academic work was irrelevant to them. Integrating science into management will be challenging.

\section{CONCLUSION}

This paper has explored the benefits, limitations, and challenges of private wildlife ranching as a tool for conservation in South Africa as seen through the perception of key stakeholders working within conservation and private wildlife ranching. All respondents believed that private wildlife ranches have a role to play in conservation in South Africa. This role is thought to be especially essential due to the limited government funding available for conservation. Wildlife ranches are seen to contribute to conservation largely by maintaining natural areas of habitat and by providing resources to support reintroduction programs for threatened species. It was suggested by a number of ranchers and professional hunters that ranching benefits conservation through breeding programs. This role was, however, disputed by a number of respondents working for conservation organizations. Other possible roles, which were not identified by our respondents, include the role of wildlife ranches as corridors in periods of climatic shift or as repositories for speciation from isolated populations under slightly different environments.

A number of limitations to the role of wildlife ranching were reported, including tourist-driven ranching (leading to a bias toward certain biomes and species), predator persecution, and inadequate professional conservation management and planning on ranches. The consequences of these limitations include the introduction of extralimital and exotic species on ranches, hybridization of species, and inadequate ecological management of ranches. These limitations largely arise due to the commercial nature of ranches, which are essentially businesses first and foremost, with differing objectives to state parks. In addition to the 
challenges of combining economic gain with conservation objectives, ranchers face a number of challenges arising because of the small enclosed character of many ranches in South Africa, including the need to intensively manage wildlife populations, in particular population numbers and predator:prey ratios.

In order to enhance the role of wildlife ranching within conservation, clear guidance and support for ranchers (from the government, NGOs, and academics) are needed in order to boost endorsement and minimize economic losses to ranchers. Furthermore, education directed toward tourists may reduce the demands placed on ranchers to provide specific species to view or hunt. The recent moves to further regulate the wildlife ranching industry, and new initiatives aimed at supporting wildlife ranchers, are the focus of ongoing research by the authors.

Responses to this article can be read online at: http://www.ecologyandsociety.org/voll3/iss2/art43/responses/

\section{Acknowledgments:}

The research for this paper was funded by a PhD scholarship in GEES at the University of Birmingham and an NERC/ESRC grant. The authors wish to thank all those who gave their time to be interviewed and two anonymous referees for their constructive comments. In addition, we would like to thank Dr Toby Gamlen for providing his Photoshop skills on Fig. 1.

\section{LITERATURE CITED}

Amalgamated Banks of South Africa (ABSA) Group Economic Research. 2003. Game Ranch Profitability in Southern Africa. The SA Financial Sector Forum, Rivonia, South Africa.

African Indaba. 2007. African Indaba. [online] URL: http://www.africanindaba.co.za. [Accessed 24 June 2008.]

Bigalke, R. C. 2000. Functional relationships between protected and agricultural areas in South Africa and Namibia. Pages 169-201 in H. H. T.
Prins, J. G. Grootenhuis, and T. T. Dolan, editors. Wildlife conservation by sustainable use. Kluwer Academic Publishers, Boston, Massachusetts, USA.

Bojö, J. 1996. The economics of wildlife: case studies from Ghana, Kenya, Namibia, and Zimbabwe. AFTES working paper 19, Environmental Policy and Planning, Environmentally Sustainable Development Division, Technical Department, African Region, The World Bank.

Boone, R. B., and N. T. Hobbs. 2004. Lines around fragments: effects of fencing on large herbivores. African Journal of Range and Forage Science 21 (3):147-158.

Botha, M. A. 2001. Incentives for conservation on private land: options and opportunities. Cape Conservation Unit Report 02/2001, Botanical Society of South Africa.

Bothma, J. du P. 2002. Game ranch management. Fourth edition. Van Schaik Publishers, Pretoria, South Africa.

Bothma, J. du P. 2004. The role and impact of larger predators on enclosed wildlife areas. Agritourism Workshop, Boscia Forum, 19-20 August 2004, George, South Africa.

Castley, J. G., A. F. Boshoff, and G. I. H. Kerley. 2001. Compromising South Africa's natural biodiversity-inappropriate herbivore introductions. South African Journal of Science 97:344-348.

Clifford, N. J., and G. Valentine, editors. 2005. Key methods in geography. Sage Publications, London, UK.

Cloete, P. C., P. R. Taljaard, and B. Grové. 2007. A comparative economic case study of switching from cattle farming to game ranching in the Northern Cape Province. South African Journal of Wildlife Research 37(1):71-78.

Conservation International. 2007. Action with a positive reaction. Newsletter April 2007, issue 3, page 2 .

Cope, M. 2005. Coding transcripts and diaries. Pages 445-459 in N. Clifford and G. Valentine, editors. Key methods in geography. Sage Pubications, London, UK. 
Department of Environmental Affairs and Tourism (DEAT). 2005. South Africa country study: situational assessment undertaken to inform South Africa's National Biodiversity Strategy and Action Plan (NBSAP). DEAT, Pretoria, South Africa.

Druce, D., H. Genis, J. Braak, S. Greatwood, A. Delsink, R. Kettles, L. Hunter, and R. Slotow. 2004. Prey selection by a reintroduced lion population in the Greater Makalali Conservancy, South Africa. African Zoology 39(2):273-284.

Dunn, K. 2005. Interviewing. Pages 79-105 in I. Hay, editor. Qualitative research methods in human geography. Oxford University Press, Oxford, UK.

Ebedes, H. 1994. Going, going, gone: an appraisal of game auctions. Pages 74-80 in W. van Hoven, H. Ebedes, and A. Conroy, editors. Game ranching: a celebration of diversity: proceedings of the Third International Game Ranching Symposium. Promedia, Pretoria, South Africa.

Evans, S. W., and K. N. Barnes. 2000. Blue swallow Hirundo atrocaerulea. In K. N. Barnes, editor. The Eskom Red Data Book of Birds of South Africa, Lesotho and Swaziland. BirdLife, Johannesburg, South Africa.

Flack, P. H. 2003. Consumptive tourism-a useful conservation tool. Pages 155-157 in D. Butchart, editor. Vision business ecotourism and the environment. Endangered Wildlife Trust, Parkview, South Africa.

Fontana, A., and J. H. Frey. 2005. The interview: from neutral stance to political involvement. Third Edition. Pages 695-727 in N. K. Denzin, and Y. S. Lincoln, editors. The Sage handbook of qualitative research methods. Sage Publications, Thousand Oaks, California, USA.

Friedmann, Y., and B. Daly, editors. 2004. Red data book of the mammals of south africa: a conservation assessment. Conservation Breeding Specialist Group (CBSG), Southern Africa (SS/ IUCN), Endangered Wildlife Trust, Parkview, South Africa.

Golding, J. S., editor. 2002. Southern African plant red data lists. South Afican Botanical Diversity Network (SABONET), Report 14, Pretoria, South Africa.
Goodman, P. S., B. James, and L. Carlisle. 2002. Wildlife utilization: its role in fostering biodiversity in KwaZulu-Natal. Pages 21-32 in S. M. Pierce, R. M. Cowling, T. Sandwich, and K. MacKinnon, editors. Mainstreaming biodiversity in development: case studies from South Africa. The World Bank, Washington, D.C, USA.

Green, W. C. H., and A. Rothstein. 1998. Translocation, hybridization and the endangered black-faced impala. Conservation Biology 12 (2):475-480.

Hall-Martin, A. J., and J. G. Castley. 2003. The status of the black and white rhinoceros on private land in South Africa. Pachyderm 34:24-32.

Hamman, K. C. D., P. H. Lloyd, and J. C. Stadler. 2005. Hunting as an acceptable management tool for conservation. Submission to the Panel of Experts, Department of Environmental Affairs, Pretoria, South Africa.

Hayward, M. W., J. Adendorff, J. O'Brien, A. Sholto-Douglas, C. Bissett, L. C. Moolman, P. Bean, A. Fogarty, D. Howarth, R. Slater, and G. I. H. Kerley. 2007. The reintroduction of large carnivores to the Eastern Cape, South Africa: an assessment. Oryx 41(2):205-214.

Helicon Services. 2007. Company Policy. [online] URL: http://www.mjvn.co.za/helicon/company policy. htm. [Accessed 24 June 2008.]

Hunter, L. T. B., K. Pretorius, L. C. Carlisle, M. Rickelton, C. Walker, R. Slotow, and J. D. Skinner. 2007. Restoring lions Panthera leo to northern KwaZulu-Natal, South Africa: short-term biological and technical success but equivocal longterm conservation. Oryx 41:196-204.

IUCN. 2002. 2002 IUCN red list of threatened species. World Conservation Union, Gland, Switzerland.

Kemp,A. C. 2000. Southern ground hornbill. Pages 117-119 in K. N. Barnes, editor. The Eskom red data book of birds of South Africa, Lesotho and Swaziland. BirdLife, Johannesburg, South Africa.

Krug, W. 2001. Private supply of protected land in Southern Africa: a review of markets, approaches, barriers and issues. Report to Environment Directorate, Organisation for Economic Co- 
operation and Development (OECD), Paris, France.

KwaZulu-Natal Hunting and Conservation Association. 2007. Code of ethics.

[online] URL: http://www.kznhunters.co.za/site/awdep. asp?dealer $=6643 \&$ depnum $=22811$. [Accessed 24 June 2008.]

Langholz, J. A., and G. I. H. Kerley. 2006. Combining conservation and development on private lands: an assessment of ecotourism-based private game reserves in the Eastern Cape. Centre for African Conservation Ecology, Report 56, Nelson Mandela Metropolitan University, Port Elizabeth, South Africa.

Leader Williams, N., S. Milledge, K. Adcock, M. Brooks, A. Conway, M. Knight, S. Mainka, E. B. Martin, and T. Teferi. 2005. Trophy hunting of black rhino Diceros bicornis: proposals to ensure its future sustainability. Journal of International Wildlife Law and Policy 8:1-11.

Lehmann, M.B., P. J. Funston, C. R. Owen, and R. Slotow. 2008. Feeding behaviour of lions (Panthera leo) on a small reserve. South African Journal of Wildlife Research 38(1): in press.

Lindberg, K., B. James, and P. Goodman. 2003. Tourism's contribution to conservation in Zululand: an ecological survey of private reserves and public. Pages 203-244 in B. Aylward, and E. Lutz, editors. Nature tourism, conservation and development in KwaZulu-Natal, South Africa. World Bank, Washington, D.C., USA.

Lindsey, P. A., J. T. du Toit, and M. G. L. Mills. 2005. Attitudes of ranches towards African wild dogs Lycaon pictus: conservation implications on private land. Biological Conservation 125:113121.

Lindsey, P. A., L. G. Frank, R. Alexander, A. Mathieson, and S. S. Romañach. 2006. Trophy hunting and conservation in Africa: problems and one potential solution. Conservation Biology 21 (3):880-883.

Lindsey P. A., P. A. Roulet, and S. S. Romanach. 2007. Economic and conservation significance of the trophy hunting industry in sub-Saharan Africa. Biological Conservation 134:455-469.

Longhurst, R. 2003. Semi-structured interviews and focus groups. Pages 117-132 in N. Clifford and
G. Valentine, editors. Key methods in geography. Sage Publications, London, UK.

Machange, R. W., A. R. Jenkins, and R. A. Navarro. 2005. Eagles as indicators of ecosystem health: is the distribution of Martial Eagle nests in the Karoo, South Africa, influenced by variations in land-use and rangeland quality? Journal of Arid Environments 63:223-243.

Marshall, C., and G. B. Rossman. 1995. Designing qualitative research. Sage Publications, Thousand Oaks, California, USA.

Meine, C., M. Soulé, and R. Noss. 2006. "A mission-driven discipline": the growth of conservation biology. Conservation Biology 20 (3):631-651.

Myers, N. 2003. Biodiversity hotspots revisited. BioScience 53:916-917.

National Agricultural Marketing Council (NAMC). 2006. Report on the investigation to identify problems for sustainable growth and development in South African wildlife ranching. Report 2006-03. NAMC, Pretoria, South Africa.

Patterson, C., and P. Khosa. 2005. A status quo study on the professional and recreational hunting industry in South Africa. Report to the Minister of Environmental Affairs and Tourism, Panel of Experts on Professional and Recreational Hunting in South Africa, Pretoria, South Africa.

Professional Hunters Association of South Africa (PHASA). 2007. About Us. [online] URL: http://w ww.phasa.co.za/index.php?pid=2. [Accessed 24 June 2008.]

Reilly, B. K., E. A. Sutherland, and V. Harley. 2003. The nature and extent of wildlife ranching in Gauteng Province, South Africa. South African Journal of Wildlife Research 33(2):141-144.

Robinson, J. G. 2006. Conservation biology and real-world conservation. Conservation Biology 20 (3):658-669.

Scholes, R. J., and R. Biggs, editors. 2004. Ecosystem services in Southern Africa: a regional assessment. Council for Scientific and Industrial Research, Pretoria, South Africa.

Scriven, L., and T. Eloff. 2003. Markets derived 
from nature tourism in South Africa and KwaZuluNatal; a survey of the sale of live game. Pages 245286 in B. Aylward and E. Lutz, editors. Nature tourism, conservation and development in KwaZulu Natal, South Africa. World Bank, Washington, D.C., USA.

Smith, N., and S. L. Wilson. 2002. Changing Land Use Trends in the Thicket Biome: pastoralism to game farming. Terrestrial Ecology Research Unit Report No. 38, University of Port Elizabeth, Port Elizabeth, South Africa.

South African Hunters and Game Conservation Association. 2007. Constitution of the South African Hunters and Game Conservation Association. [online] URL: http://www.sahunt.co.za/ uploads/constitution NOV06.pdf. [Accessed 24 June 2008.]

Steenkamp, C., D. Marnewick, and K. Marnewick. 2005. A status quo of the conservation impacts from the professional and recreational hunting industry. Report to Minister of Environmental Affairs and Tourism, Panel of Experts on Professional and Recreational Hunting in South Africa, Pretoria, South Africa.

Strauss, A., and J. Corbin. 1990. Basics of qualitative research: grounded theory procedures and techniques. Sage Publications, London, UK.

Thaba Manzi Wildlife Services. 2007. Mission Statement. [online] URL: http://www.thabamanzi.co. uk. [Accessed 24 June 2008.]

The Convention on Biological Diversity. 1993. Article 2. Use of Terms. [online] URL: http://www. cbd.int/convention/articles.shtml?a=cbd-02. [Accessed 24 June 2008.]

van der Merwe, P., and M. Saayman. 2003. Determining the economic value of game farm tourism. Koedoe 46(2): 103-112.

van der Merwe, P, M. Saayman, and W. Krugell. 2004. Factors that determine the price of game. Koedoe 47(2):105-113.

Wynberg, R. 2002. A decade of biodiversity conservation and use in South Africa: tracking progress from Rio Earth Summit to the Johannesburg World Summit on sustainable development. South African Journal of Science 98:233-243.
Yin, R. K. 1994. Case study research: design and methods. Sage Publications, Thousand Oaks, California, USA.

Zunckel K., and S. F. de Wet. 1994. Veld conditions assessment of some game farms and nature reserves in the eastern Transvaal Lowveld during the 1991/92 drought. In W. van Hoven, H. Ebedes, and A. Conroy, editors. Wildlife ranching. a celebration of diversity. Promedia, Pretoria, South Africa. 